\title{
OCCULT COLLECTIONS AND MYSTERIOUS COINCIDENCES AT RUTGERS
}

\author{
BY ERIKA GORDER \\ gorder@rulmail.rutgers.edu
}

\section{Introduction and the Exhibition}

Beginnings

In spring 2014, I curated an exhibition, "Unheard of Curiosities": An Exhibition of Rare Books on the Occult and Esoteric Sciences, drawn from and inspired by two collections: the Fairweather Occult Collection and the J. F. C. Fuller papers. ${ }^{1}$ The exhibition, in turn, inspired a colloquium on Aleister Crowley and J. F. C. Fuller at Rutgers on June 23, 2014. These two collections came to Rutgers University's Special Collections and University Archives (SC/UA) more than 30 years apart. Together they form significant documentation on the occult and esoteric sciences, although some might consider Rutgers an unlikely place for such collections. From Rutgers University Libraries perspective, that either collection contained material on the occult theme was accidental: the libraries had neither explicitly nor formally sought to collect in the area of the occult or occult revival. Further examination of the provenance of these collections revealed some mysterious coincidences at Rutgers.

The exhibition itself was years in the making. From the time of its acquisition in 2003, SC/UA staff were enthusiastic to curate an exhibition showcasing the Fairweather books. My area of expertise is American history and the history of Rutgers University, but I had long been intrigued by the collection. When a slot opened in our exhibition schedule, I offered to curate the exhibition. With the help of head of exhibitions Fernanda Perrone, our rare book cataloger Silvana Notarmaso, and two intrepid graduate students Becca Feest and Meghan Rinn, we embarked on the project, first examining the diverse collection of more than 300 volumes. What we discovered was its breadth and scope which, interestingly, is by and large a http:/dx.doi.org/10.14713/irul.v67i0.1895

Journal of the Rutgers University Libraries, Volume 67, pp 19-55. 
collection of works on astrology with some alchemy, Egyptology, astronomy, and witchcraft mixed in.

\section{The Exhibition}

"Unheard of Curiosities": An Exhibition of Rare Books on the Occult and Esoteric Sciences showcased rare books from Special Collections and University Archives that display evidence of the enduring popular interest in a diverse constellation of "occult" topics from the sixteenth century to the present day. The exhibition primarily features books collected by the late Rutgers professor of English, Clement Fairweather (the "Fairweather Collection"), which predominantly center on astrology and early astronomy from the seventeenth through the nineteenth centuries. Secondary topics include prediction and prophecy, demons and the devil, witchcraft and magic, the mysteries of ancient Egypt, and the nineteenthand early-twentieth-century occult revival. A temporal rift in the collection is evident, roughly divided between works from the seventeenth and the nineteenth centuries. The exhibition's topical boundaries were drawn by the Fairweather Collection itself-both its strengths and weaknesses-including astrology, astronomy, astrological medicine, alchemy, and hermeticism, witchcraft, and prophecy and prognostication. Some topics, though not documented with great depth in the Fairweather Collection, were nonetheless featured because of their novelty or significance within the framework of the history of the occult. These include Merlin, magic and spells, Aleister Crowley, Egyptology, and cartomancy. However, not all topics that may be considered "occult" or "esoteric science" to the contemporary audience were represented either in the exhibition or in the collection itself.

\section{The Occult as a Topic}

The "Occult," like beauty, is in the eye of the beholder. To the contemporary mind, it may conjure up any combination of a legion of topics from astrology, fortune telling, Ouija boards, séances, pagan ritual, witchcraft, zombies, conjuring demons and summoning the dead, alchemy, magic, and the list can go on and on. It has come to be an umbrella term for any number of beliefs or practices deemed "unscientific" — shunned and forgotten knowledge-or perhaps more importantly, that which exists on the fringes of mainstream or popular belief systems. As a topic, the classification known as the occult is of relatively 
recent provenance. "Esoteric Sciences," a term that is often used synonymously or interchangeably with the occult and is similar to its world view, is a category of philosophy and practices that include mystical and religious philosophies stretching back to antiquity such as Babylonian astrology, Orientalism, hermetic philosophy, Gnosticism, Kabbalah, and alchemy. Areas of inquiry now dismissed as superstition such as astrology, alchemy, and natural magic made real contributions to early science. However it was not until the culmination of the scientific revolution of the late seventeenth century with the publication of Isaac Newton's Philosophice Naturalis Principia Mathematica (1687) that these disciplines, which were once illuminated in the scholarship of countless earlier scientists, philosophers, poets, mathematicians, and physicians, became "hidden" or esoteric. The end of the seventeenth century marked by Newton and the so-called "Scientific Revolution" signaled the marginalization of astrology, alchemy, and similar fields of inquiry as "pseudo-science" or popular superstition.

The seventeenth-century Age of Reason paved the way towards modern science, which developed during the eighteenth-century Age of Enlightenment. The works of Newton, Descartes, Pascal, and Leibniz led to the development of modern mathematics, physics, and technology. The impact of the Age of Reason was not limited to science and technology but also philosophy, religion, and society and politics in general. By the eighteenth century the European world view was decisively altered by the scientific revolution. The Newtonian model influenced other sciences, breakthroughs were made in chemistry, taxonomic systems allowed natural historians to catalog the myriad organisms and minerals found in nature; mathematicians began to apply theoretical, deductive thought to physical reality, astronomers looked beyond the solar system to study the origins of the universe itself, and medical research advanced. Yet these changes posed a dilemma. Religion experienced its own crisis during this period and eventually reflected rationalism, materialism, deism, growing agnosticism and skepticism, positive atheism, and the rise of secularism. Scholars found it increasingly difficult to bridge the gulf between natural and supernatural and to reconcile natural law and divine providence.

Some historians suggest that the reaction to this new paradigm brought "the occult" into existence, primarily by Enlightenment and Romantic figures who, according to Gary Lachman 
". . . found a body of rejected knowledge, a counter-history and alternative narrative to human existence, one that ran parallel to the increasingly successful scientific view. And as it dealt primarily with inner, spiritual things, it was one that readily lent itself to this sensitive minority. . ."2 Certainly the new scientific world view was a significant and important development in European and world history. But the legacy of that revolution meant that scientific logic was sufficient to measure, classify, and explain all phenomena, including human emotion, aesthetics, values, and the unfathomable. The resulting cultural and philosophic crisis was articulated by a small, but growing counter-culture. Out of this came the assemblage of rejected knowledge that makes up the occult.

\section{The Collections in Context}

The study of the occult encompasses a wide array of topics and is truly interdisciplinary from the perspectives of intellectual history, the history of science and medicine, religion studies, Orientalism and colonialism, Near East studies, women's history, folklore, and popular culture studies. What the modern academy has traditionally placed in the realm of the occult has recently received renewed scholarly attention. Modern scientists have long dismissed the connections between alchemy and chemistry or astrology and astronomy, but historians of science and medicine have recently shown the roots of these disciplines. ${ }^{3}$ For instance, prior to the scientific revolution of the late Renaissance-exemplified by astronomers such as Copernicus, Galileo, Kepler, and Braheastrology and astronomy were considered complementary sciences. So intertwined, the distinctions between astrologers, astronomers, alchemists, and physicians are difficult to discern. Indeed, even giants of the time, astronomers such as Galileo and Copernicus were also practicing astrologers. So too, the practice of astrology and medicine went hand-in-hand from the medieval period into the eighteenth century. Well into the sixteenth century, the connection between medicine, astronomy, and astrology in university curricula and in the work of physicians was a close one. The relationship of medicine and astrology persisted beyond the ancient medical theory and the Renaissance and flourished in seventeenth century Europe and England. Not only was it studied by scholars and practitioners, but was known by the general public. Even as academic and elite acceptance of astrology was on the wane in the late seventeenth century, pockets of belief endured in popular folk practice. 
Witchcraft has long been a significant area of historical inquiry for feminist scholars and historians. Indeed the study of witchcraft and magic can arguably be considered one of the cornerstones of early women's history scholarship. Similarly, a significant portion of the study of the occult, particularly in the late nineteenth century, is framed in terms of colonialism. The mutual influences on the "East and West" have ancient origins, demonstrated by the study of Egypt and the long history of Egyptomania in Europe and the United States. ${ }^{4}$ Both the science and religion of Egypt and the Near East directly influenced the culture of the Mediterranean for centuries. Even later in the nineteenth century, British and European conquests of the Near East, Africa, and India these influences are clearly evident by its imprint on the Victorian fascination with the religious and scientific heritage of these conquered regions. The study of Orientalism, therefore, is critical to our understanding of the political and cultural ramifications of colonialism which includes a serious view of the religion, culture, and science in the Near East.

In the exploration of the early history of humankind's attempt to explain and control the cosmos and natural world, scholars have begun to take into account the real contributions made to early science by areas of inquiry now dismissed as magic or superstition under the rubric of the "occult," such as astrology, alchemy, and natural magic. Current scholarship and new avenues of academic inquiry are also concerned with "boundary work" a major theme analyzing the way in which societies have defined and enforced the boundary between, for instance, what they define as "magic" and what they view as legitimate "science." The broader implications of boundary work is interdisciplinary as scholars examine the intersections among science, the occult, religious and spiritual culture, art, popular culture, and politics. This approach addresses the complex relationship between science, magic, and religion.

In addition to boundary work studies, the interdisciplinary study of occult topics can contain analyses of its role in popular culture. ${ }^{5}$ The sixteenth and seventeenth century saw the publications of books on alchemy and astrology in almost every European language. These works were widely distributed and consumed by an audience of skeptics and believers alike. Throughout history, the desire to look into the future has been an indelible feature of human culture. Prophecy and divination have been characteristic, and even form the foundation of, many of the world's religious 
practices. So too has fortune-telling and predictive astrology captured man and woman's curiosity about their personal fates. Put to practical use, astrological and astronomical predictions regarding the seasons and weather were important to agricultural and maritime endeavors. In the seventeenth century, astrological prediction for entire nations and their rulers was widespread and this type of prophecy was closely connected to national identity and often highly politicized. Whether motivated by practical or spiritual reasons, or merely for entertainment, society's obsession with the future is a strong and enduring cultural influence. The Fairweather collection with its concentration on astrology, specifically hugely popular authors such as William Lilly, Nicholas Culpeper, and Antoine Mizauld provides a rich ground of source material for scholars or students examining this aspect of popular culture.

While the study of the occult draws from many academic disciplines, the study of esotericism, more specifically, Western esotericism, has emerged as an area of scholarship in its own right. Western esotericsm refers to a broad spectrum of historical currents in western culture from antiquity to the present day. Most notably the Hermetic philosophy of the Renaissance, mysticism and magic, spiritualism, alchemy, astrology, theosophy, Gnosticism, Kabbalah, Paracelcianism, Rosicrucianism, and the many occultist and related esoteric currents that developed during the late nineteenth and early-twentieth centuries: modern Occultism, Spiritualism, Traditionalism, the New Age movement, Neopaganism, Ritual Magical groups, and a host of contemporary alternative spiritualities. One common uniting feature of this diverse array of philosophies and practices is that they have ostensibly been rejected by mainstream religious and academic institutions in the West. Therefore the study of esotericism is primarily concerned with those disciplines excluded from the Western intellectual and cultural canon in the wake of the scientific revolution. As a result, its scholarship was largely left to amateurs, Romantics, nineteenthcentury occultists, and their intellectual heirs up to the present time. Western esotericism as a scholarly category has emerged again within the academy in the United States and Europe as exemplified by numerous university programs, associations, recent conferences, and scholarly journals. ${ }^{6}$ 


\section{Clement Fairweather (and His Books)}

Clement Fairweather

Clement W. Fairweather Jr. was a professor of English at University College of Rutgers University from 1947-1984. He was born in Grantwood, New Jersey, in 1913 and was a lifelong resident of Metuchen, New Jersey. Fairweather graduated from Rutgers

College in 1935 and completed a

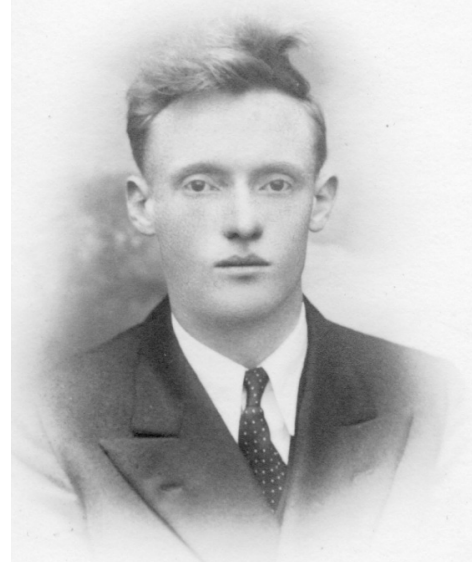

Clement Fairweather as a young man, n.d. doctorate in English literature at Princeton University in 1942. His advisors described him as a shy but brilliant student, who exhibited an early interest in collecting. Known as "the gag man," by 1935 he had collected over 30,000 jokes clipped from newspapers and magazines. His doctoral thesis, "English Sermon Wit, 1550-1660," reflected this avocation. ${ }^{7}$ After service as a technician in the infantry during the Second World War (1941-1946) and surviving the Battle of the Bulge, Fairweather was appointed as assistant professor of English at University College, Rutgers, in 1947. University College was established in 1934 for the purpose of bringing academic training to men and women who could attend college only in the late afternoon and evening and therefore served primarily adult and part-time students and was coeducational (the first coeducational college at Rutgers). Fairweather taught at the university until his involuntary retirement in 1984. This was most likely the result of the merger and streamlining of the various English department faculty at Rutgers, resulting from academic reorganization in New Brunswick in 1981. After his retirement Fairweather enrolled in and nearly completed law studies at Rutgers University. ${ }^{8}$ As a professor, he focused on his teaching and little was evident, or known, about his collection on the occult and esoteric sciences and British poet and writer Walter De La Mare. Later in life Fairweather became eccentric and isolated from society, but was befriended by his neighbors Marty Kelley and Bogie Boscha who kept tabs on him, completely unaware of his collection. When he died in 2000, as executors of his estate they discovered the vast collection of books in his large and dilapidated house in Metuchen. 
Ron Becker, head of Special Collections, Michael Joseph, curator of rare books and other Rutgers University Libraries librarians inventoried and assessed the collection, selecting the more than 300 volumes which were donated to the Rutgers University Libraries in Fairweather's name.

While one could say that the exhibition of the Fairweather collection was a reflection of both the collection and collector, for a faculty member for nearly forty years, it is peculiar that we know little about Fairweather and his motivation for collecting or even how long he had been acquiring books. Rutgers does not have his personal papers, memoirs, other writings or scholarship, or acquisition records that could shed light on this collection. It merely speaks for itself that with the acquisition of the Fairweather collection, Special Collections and University Archives has become an important source collection for astrology and the occult (see appendix).

\section{Fairweather, the Mysterious}

As a faculty member for thirty-seven years, Clement Fairweather left behind very few clues. The University Archives has a scant biographical file and few records of University College and its departments during this time period. In the absence of specific course syllabi, the catalogs for the college list faculty for each department in general, but do not identify specific faculty members with their course offerings. Fairweather did not publish in scholarly journals or produce any other academic works other than his $\mathrm{PhD}$ dissertation. ${ }^{9}$ However, this dearth of publication evidence does not necessarily indicate that he did not pursue scholarly research. One significant document in the archives sheds some light on this-a transcript of remarks given by a colleague at Fairweather's retirement party. The speaker is unidentified but evidently a retired faculty member who was called upon to make remarks. This transcript is the only extant record that gives us any concrete evidence about the personality of this man or gives us any insight into his collection. ${ }^{10}$

Fairweather is described as extremely shy, retiring, reticent, and gentle but also described by students and colleagues alike as a "roaring lion in the classroom," a taskmaster, principled, and independent. The speaker's opening remarks perhaps do not come as a surprise, though clearly this colleague was, if not a good friend, an admirer: "In a sense, I welcome this task, for it may be 


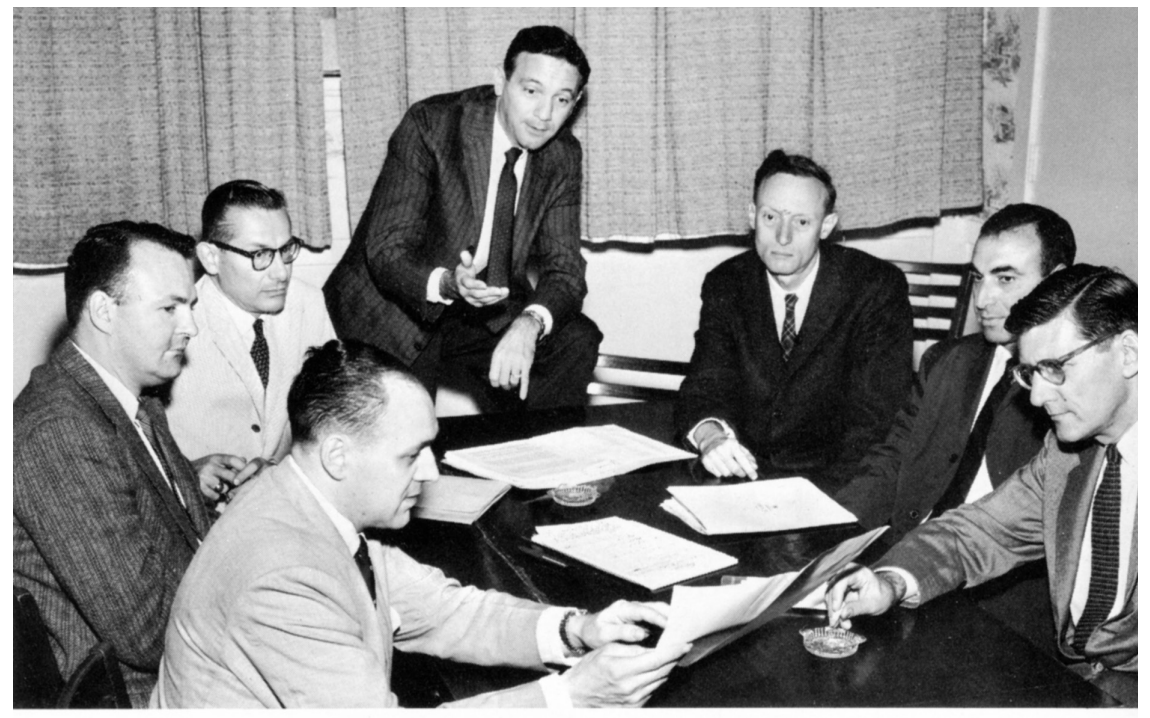

ENGLISH AND THE HUMANITIES

James Macris, John Zawadsky, Richard E. Hawes, David Lilien, (Chairman); Clement W. Fairweather, William J. Fisher and William M. Wynkoop.

Faculty of University College English Department, 1961. Clement Fairweather is seated third from right.

because of his extremely retiring nature, that it is high time, even as he leaves, that he should be introduced to you. ${ }^{11}$ While this may show evidence of a reclusive personality, it should be noted that during the thirty-seven years Fairweather was at Rutgers, not only did the University experience phenomenal growth, so too did the English Department of the University College, both prior to and especially after academic reorganization. It is hardly surprising that a faculty member at the evening college may not have been easily recognizable. But still, it seems as if Fairweather preferred to carve his own academic path ". . . according to his own light, in keeping with his own principles, consistent with his own temperament."12

It is vexing that there is no clear evidence to be found on Fairweather's academic interests other than his dissertation which cannot be the sum of his intellectual identity. But, the most satisfying, and, significantly, the only direct quote and observation about it is attributed to Professor Fairweather himself:

"When I began my teaching career," he once wrote, "I made a conscious and deliberate decision to address myself to the problem of becoming a good teacher. Why did I make such 
a stupid decision? I say "stupid" because it certainly was stupid from certain viewpoints - that of advancement and status within the academic community. In these respects the decision has badly damaged me. Nevertheless, I believe it was the right decision. It was right because I was being true to myself in making it. I have found the classroom experience sheer delight. And I have taken deep satisfaction in watching my students grow."13

I note, but won't quote that several times in this speech reference is made about "Clem" staying true to himself and his personality to focus on teaching rather than research and publication. He seems to have devoted his scholarly pursuits to his course preparations. An example of which were his voluminous studies of the literary works he considers in his advanced courses:

In effect, he never considered himself adequately prepared until he had compiled his own variorum edition of a work he was about to teach. I have come to know several of these studies, and I have marveled at the time and energy that must have been expended in explicating these texts with the fullest philosophical, critical, historical, and textual notes touching every word or passage requiring clarification or comment. ${ }^{14}$

Several anecdotes from former students show that Fairweather's scholarship and knowledge was indeed prodigious and equaled only by his dedication to teaching and the scholarly preparation of his students: he gave his own time to both a seminar in research techniques (which he felt was woefully ignored in the Rutgers curriculum) and again devoted his own time to teaching his students Middle English in order to read Chaucer so that "the poetry would sing." 15

While this information gleaned from one document in the archives reveals much on Fairweather's classroom style and academic philosophies, almost nothing is known of his interest in astrology and the "occult." Several vague passages allude to his "strange" lifestyle and reinforce the idea of his own self-fidelity, one can only speculate on the following comment:

Clem was true to himself in still another way. Although many of us may not care to embrace Clem's lifestyle-and who is 
to say what the good life is - all of us must at least admire him-shall I say envy him? - for having successfully, for thirtyseven years, travelled his independent academic and personal course. $^{16}$

And now we get to the part that perhaps sheds a sliver of light on Fairweather's rare book collection. He had been criticized by the occasional student for going off topic in his lectures and "...I think I would have been pleased to sit before him to pick up some of his life-saving bits of wisdom....After all, an understanding of the merits of herbal nutrition may be far more valuable than an ability to identify a rhetorical antitheses." The speaker proceeds to then describe Fairweather's aversion to medicine and doctors, preferring a good dose of garlic to heal an abscessed tooth rather than visit a doctor or dentist. ${ }^{17}$

It seems fair to say that Fairweather's interest in natural remedies and herbals is clearly reflected in the collection. His collection consists primarily of works on astrology-both predictive and medical-with particular strengths in the works of William Lilly, Nicholas Culpeper, and Antoine Mizauld. What is borne out even at first glance at the collection-but also upon further research and investigation of the topic-is that from the sixteenth to eighteenth centuries astrology, herbals, almanacs, and medicine went hand in hand.

\section{Walter De La Mare Collection}

Even as Fairweather's occult book collection is primarily one that documents astrology and its relationship to the early sciences, there is admittedly a vague confluence of the "other worldly» or occult topics that one can glimpse from his library. In addition to the approximately 300 rare books on occult topics, Fairweather also collected the works of twentieth-century British poet and writer Walter De La Mare who was known not only for his children's stories and poems, but for his ghost stories. While one could argue that the ghost and horror genres are distinct from the occult, the influence of the occult sensibility on the gothic and macabre should not be understated. The famous American cult author H. P. Lovecraft ${ }^{18}$ cited De La Mare's novel The Return (1910) as a significant influence and in his seminal literary criticism Supernatural Horror in Literature (1945), gave De La Mare special distinguished notice: 
As a forceful craftsman to whom unseen mystic world is ever a close and vital reality is the poet Walter De La Mare, whose haunting verse and exquisite prose alike bear consistent traces of a strange vision reaching deeply into veiled spheres of beauty and terrible and forbidden dimensions of being." 19

Hans (Hansi)("Jack") Hammond

It is important (or tempting) to note, in this growing tale of coincidences, that also on the staff of University College during at least part of Fairweather's long tenure there was Hans Hammond. He first appears in the directory in 1965 as an Assistant Dean at University College and is in that position until at least 1968. Hammond was famous as a child, who, according to the tabloids of the 1920s, was a "wild child" of an occult commune in Italy. His mother, Leah Hersig was an associate of Aleister Crowley and his "Scarlet Woman" (a figure in Crowley's spiritual movement, Thelema). As a youth, Hammond gained some notoriety in the sensational press who named him the "adopted son" of Aleister Crowley and "Beast No. 2" (Crowley himself was called "The Beast") as reported in at least two magazines, in 1924 and 1931. ${ }^{20}$ It is unclear if Hammond and Fairweather were friends, or if they had any contact as colleagues but they were definitely at University College at the same time.

Between the coincidence of Hammond and Fairweather at University College and clearly Fairweather's interest in De La Mare, there looms some aspect of the unknown, these spirit apparitions that we see out of the corner of our eyes but can't quite grasp, describe, or map, I think makes this story all the more mysterious and appealing. My skepticism about the "occult" or mystical nature of the collection aside, the connection-or at the very least coincidence-of Fairweather, with his unconventional behavior, and Hans Hammond working together is fascinating. One can only guess if they were more than acquaintances let alone friends who may have influenced each other. Because of the reclusive nature of Fairweather and the general dearth of information about him, any commentary on his actual beliefs vis-a-vis the occult or any relationship with Hammond (assuming that Hammond would have ever mentioned his notorious past) would be pure speculation. The Fairweather connection with Hammond is tempting to entertain but are we desperately grasping at apparitions? Are these circumstantial and imaginary coincidences? If not a real intellectual 
connection - the bridge from Fairweather to Hammond to Aleister Crowley to J. F. C. Fuller-it still is a conceptual one that has a certain amount of abstract elegance.

\section{JFC Fuller Papers and Aleister Crowley}

In preparation for Unheard of Curiosities, I noted that there was but one title of Aleister Crowley's work, Book 4 (1911), ${ }^{21}$ in the collection and felt that it should be featured. I embarked upon the search for other Crowley material to augment that section of the exhibition. I had heard rumors of Crowley material in the J. F. C. Fuller Papers and with some vague information from one of my colleagues descended to the vault to examine the X-Fuller book collection and the Fuller papers. On the day that I had chosen to explore Fuller, I was downstairs perusing the titles, puzzled as to why there were these Crowley-related titles amongst books about tanks! As I was marveling at the dichotomy, a colleague told me that there was a researcher in that very day looking at the Fuller papers! And that is when I met a researcher from the Ordo Templi Orientis (O.T.O.). ${ }^{22}$ Such a fortuitous meeting that ultimately led to the loan of paintings for the exhibition that J. F. C. Fuller created for the O.T.O. and an eye-opening realization of what SC/UA had in our collections. The final result was a beautiful addition to the

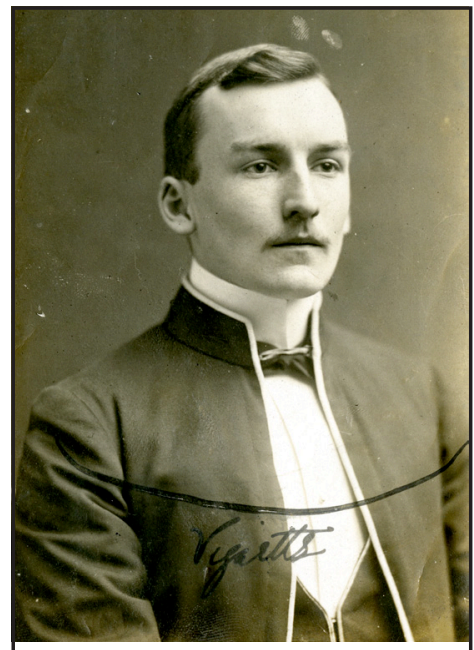

J.F.C. Fuller as a Sandhurst cadet ca. 1897, just prior to his official commission to the $1^{\text {st }}$ Battalion of the Oxfordshire Light Infantry in August 1898. show as Fuller was a talented artist and draftsman as well as brilliant military theorist and historian. This accident of research also led to the colloquium at Rutgers University Libraries, "The Soldier and the Seer: J. F. C. Fuller, Aleister Crowley, and the British Occult Revival." co-sponsored by the Academia Ordo Templi Orientis. ${ }^{23}$

\section{J. F. C. Fuller}

Major General John Frederick Charles Fuller was born in 1878 in Chichester, England, and was educated at Malvern, Sandhurst, and British Army Staff College, taking his Army Commission in 1898 with the Oxfordshire Light Infantry. He 
served in the Boer War in South Africa from 1899 to 1902 and in the spring of 1904, Fuller was sent with his unit to India, where he contracted typhoid fever and returned to England in 1905 on sick leave. Instead of returning to India, he was reassigned to units in England until he was accepted into the Staff College at Camberley in 1913. Highly decorated, he was the recipient, along with his good friend General Sir Basil Liddell Hart, of the Chesney Memorial Medal of the Royal United Service Institution for 1963. ${ }^{24}$

Innovative in the burgeoning field of armored warfare, specifically tanks, Fuller distinguished himself as commander of tank division in the Battle of Cambrai in 1917. During the First World War, he was a staff officer with the Home Forces and with 7 Corps in France, and from 1916 in the Headquarters of the Machine-Gun Corps' Heavy Branch which was later to become the Tank Corps. He planned the tank attack at the Battle of Cambrai in 1917 and the tank operations for the autumn offensives of 1918. In the 1920s, he collaborated with B. H. Liddell Hart in developing new ideas for the mechanization of armies. Less acknowledged by his colleagues in Britain, his ideas on mechanized warfare continued to be influential leading up to the Second World War, ironically more with the Germans. In the 1930s, the Wehrmacht implemented tactics similar in many ways to Fuller's theories, which became known as "blitzkrieg."

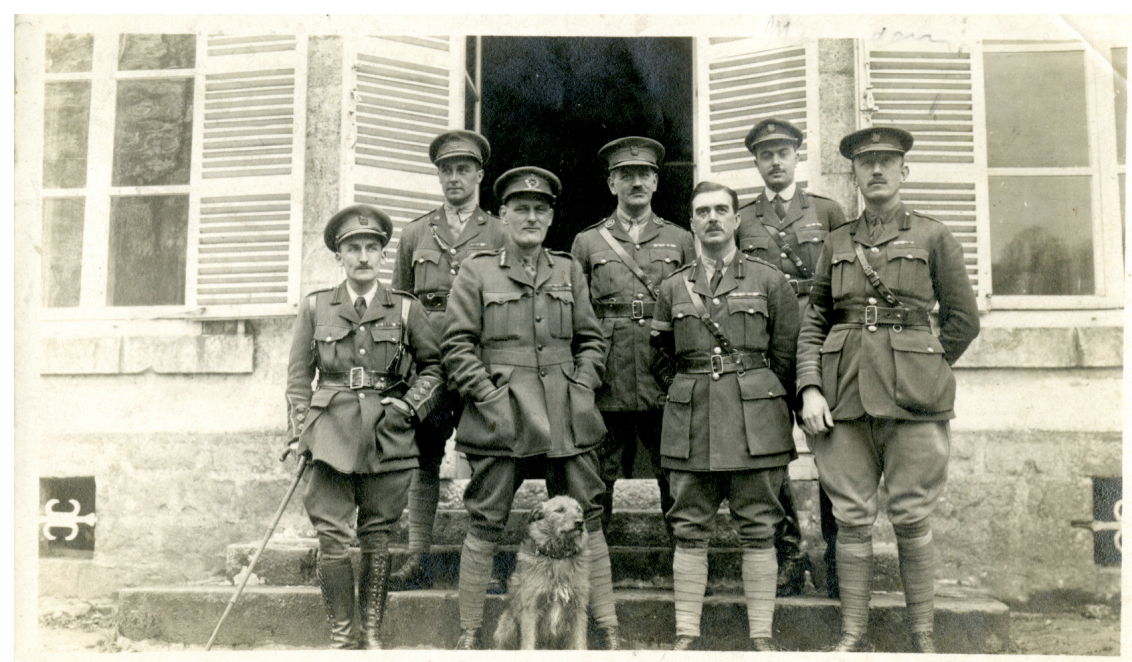

J.F.C Fuller, Colonel Hugh Elles, and Captain T.J. Uzielli (from the left in the front row) and others at the Heavy Branch Headquarters at Bermicourt near Agincourt, France, ca. 1917. 
On his retirement from the army in 1933, Fuller became involved with Sir Oswald Mosley and the British Fascist movement. As a member of the British Union of Fascists he sat on the party's Policy Directorate and was considered one of Mosley's closest allies. On April 20, 1939, Fuller was an honored guest at Adolf Hitler's fiftieth birthday celebration and during the opening parade watched as "a completely mechanised and motorised army roared past the Führer." Afterwards Hitler asked, "I hope you were pleased with your children?" Fuller replied, "Your Excellency, they have grown up so quickly that I no longer recognize them." 25

Fuller was a meticulous, expressive, and opinionated writer of military history and of controversial predictions of the future of war. Military historians have acknowledged that he was a capable analyst and many of his views were vindicated by events. Until his death in 1966, Fuller wrote continuously, authoring nearly forty books on military tactics, history, and military history. His primary (if not exclusive) publisher in the United States was Rutgers University Press.

The J. F. C. Fuller Papers at Rutgers University Libraries, Special Collections and University Archives have garnered attention in recent years for its materials related to Crowley. While stationed in India, Fuller discovered Aleister Crowley and had entered, and won, a contest to write the best review of Crowley's poetic works (he was, apparently, the only entrant to the contest). This essay was later published in 1907 as The Star in the West: A Critical Essay Upon the Works of Aleister Crowley, Fuller's first book. After this he became an enthusiastic supporter of Crowley and in turn Crowley was his intellectual mentor. Fuller was a member and later Chancellor of the magical order, the A. ·.A. · ., founded by Aleister Crowley and George Cecil Jones, which sought to reform the British occult group the Hermetic Order of the Golden Dawn; he was co-editor of its journal, The Equinox from 1909 to 1910. During this period he wrote The Treasure House of Images, edited early sections of Crowley's autobiography The Temple of Solomon the King and served as the primary illustrator for Equinox. Crowley and Fuller had a falling out in 1911 after the Jones vs The Looking Glass case and Crowley's silence in defense of Jones. ${ }^{26}$ Fuller became concerned that his association with Crowley might be a hindrance to his career. While his relationship with Crowley was short lived, both men were instrumental in the other's spiritual, social, and intellectual development. Fuller was also interested in Yoga and Kabbalah ${ }^{27}$ 
topics that may have once been considered the "occult" but are now accepted in mainstream society. ${ }^{28}$

Acquisition of the Fuller Papers

Much like the acquisition of a major collection of occult books from the Clement Fairweather estate, 34 years earlier Special Collections and University Archives acquired a collection of importance in the study of the occult, esoteric sciences, and Aleister Crowley. Although the "occult" importance of Fuller's papers was unknown to the University Library at the time, it was also acquired by "accident" as neither esotericism nor European military history were a collecting area at that time. Indeed Rutgers is an unlikely and unexpected repository for these subjects, so why do we have Fuller's papers?

The simple reason is that Fuller was working on a book, The Conduct of War, published by the Rutgers University Press (1961). From the late 1950s until his death, Fuller engaged in lively and intense correspondence with William Sloane, director of the Rutgers University Press, and his associate Helen Stewart. ${ }^{29}$ This correspondence chronicled Fuller's life and career with incredible detail and candor. In a letter to Fuller in March 1962 Sloane broached the subject: "Your letter also reminds me that I have now received a lot of fascinating and valuable letters from you.... have you designated any set of archives or made an arrangements about your papers and letters?..." 30 As he felt the end of his life was drawing near Fuller responded:

"You ask me about personal archives. I can't say I have any of the name ... [he then goes into some detail about memoirs of South Africa and WWI and commented that he did not have a secretary]. . .the latter, with most of my papers, letters, etc. that had survived up to 1939 were in 1940, when stored in a warehouse destroyed in the blitz of London...For this I really had to thank Hitler. ." He then continues to catalog his own history including reference to attending Hitler's 50th birthday celebration-"a most interesting occasion." 31

Then, at the end of 1962 he writes to Sloane in regards to his books and papers and makes a suggestion: "such heirs as I have are distant ones, and in any case are not interested in my work, nor do I know of any institution in this country which is...what I suggest is that I have a clause inserted in my will leaving all these things to you to do with as you see fit." 32 
After discussions between Sloane and University Librarian, Donald "Scotty" Cameron, Rutgers agreed to accept Fuller's papers. ${ }^{33}$ It is important to note that little, if any, reference was made to Fuller's relationship with Crowley or A. .A. . and the merits of the collection were assessed regarding their importance in military history and European history. Indeed, Cameron wrote

...the fact that I think the general is as mad as a hatter has nothing to do with the desirability of his papers. We will be very happy indeed to have them...it is a shame that the papers representing the career between the wars has been lost. Do you know that I have read everything the old boy wrote since the early 1920s? I would regard it as an addition to our resources, and will be very happy to have a part in making arrangements for their reception. ${ }^{34}$

As a result, Special Collections and University Archives is in possession of a collection that is of significance to both modern European history and the Western esotericism.

Description of the Fuller papers

The J. F. C. Fuller Papers 1848, 1893-1965 (MC 1250) are contained in 18 manuscript boxes and 9 scrapbooks. They were acquired by gift of William Sloane in September 1968. Previously they were received by Sloan as a bequest of Fuller in June 1967. The bulk of the papers concern Fuller's writings and include material from journal articles and letters to newspapers; research notes and clippings; and drafts and galleys of published and unpublished works including (original titles as found in the collection): The Generalship of Julius Ceasar (later titled Julius Caesar, Man, Soldier, Tyrant), The Conduct of War, The Generalship of Alexander the Great, and the Foundation of the Imperial Army; The Foundations of War. Related to his publishing are reviews of published works and publication agreements and contracts (1928-1957.) The Fuller papers also include photographs of battlefields, World War I tanks, family and personal friends, and two diaries. The Italo-Abyssinian Diary, 1935 a 22-page war journal kept in Ethiopia and Italy from October to November 1935 which records Fuller' observations of the Ethiopian war as a correspondent. The second diary, Report on India is a 44-page journal of a military tour from October to December 1926 through India and what is now Pakistan. As a 
high ranking officer attached to the British War Office to "establish a personal link between the W.O. and Delhi. .." the journal documents the Indian military and political situation and the mechanization, tanks, Indianization of the army, Afghanistan, Russia and the Staff College at Quetta, in Baluchistan, British India, now Pakistan. ${ }^{35}$

Of special significance, the first three boxes of the Fuller papers contain correspondence from 1893-1965. Predominantly letters received, among them include the correspondence between Fuller and the Rutgers University Press, and various military and political colleagues including most notably, Winston Churchill, Field Marshall William Edmund Ironside, and Brigadier J. Gilbert Browne. The letters from J. Gilbert Browne were written during his assignment with the Iraq Levies primarily from Mosul, Iraq in 1928 and include hand-drawn maps. ${ }^{36}$ The voluminous correspondence between Fuller and Ironside was primarily during the time of Ironside's command of the Meerut district in India in the late 1920s and later as Quartermaster-General in 1933. Ironside became Commandant of the Staff College in 1922 and there became a mentor of Fuller who was then lecturer at the College, and became a close acquaintance with Basil Liddell Hart, also close friend of Fuller. The letters of Ironside in the J. F. C. Fuller papers reveal a candid relationship including one comment from Ironside to Fuller, "I miss you terribly." ${ }^{37}$

J. F. C. Fuller's relationship with British fascism is well known and several items in the collection are cause for some notoriety. In 1939, Fuller was invited to Adolph Hitler's fiftieth birthday party, which he attended. In the collection is the invitation to the April 20, 1939, celebration, printed on Nazi stationery with companion seating chart and program. The event included a procession of tanks and the opera Die Lustige Witwe: Operette von Franz Lehar (The Merry Widow) at the Deusthces Opernhouse Berlin. Also included is Fuller's letter to the editor of the Times on April 24, 1939 regarding his attendance at the event.

In stark contrast to the papers related to Fuller's military career, writing on military tactics, theory and history, stands the materials related to Aleister Crowley. While not comprehensive or complete, the items are nonetheless significant. Included are publications: "The Rights of Eleusis" pamphlet from the Equinox (undated); Liber LXI; "AHA! The Sevenfold Mystery of the Ineffable Love...." From Equinox (Vol. I, no. 3: March 1910); first edition of 
Aleister Crowley's Sword of Song Called by the Christians the Book of the Beast (1904); Fuller's copy of the Kasidah of Hanji abda Al-Yazdi: A Lay of the Higher Law by Captain Sir Richard F. Burton (1900) with holograph note on the front leaf (possibly in Fuller's hand) stating: "this copy contains Aleister Crowley's corrections, 1906"; a full copy of the Looking Glass, May 6, 1911, containing the controversy that estranged Fuller from Crowley; signed copy 2 of the first edition of Star in the West; and the original artwork by Fuller for "Liber 231" including tables of sigils.

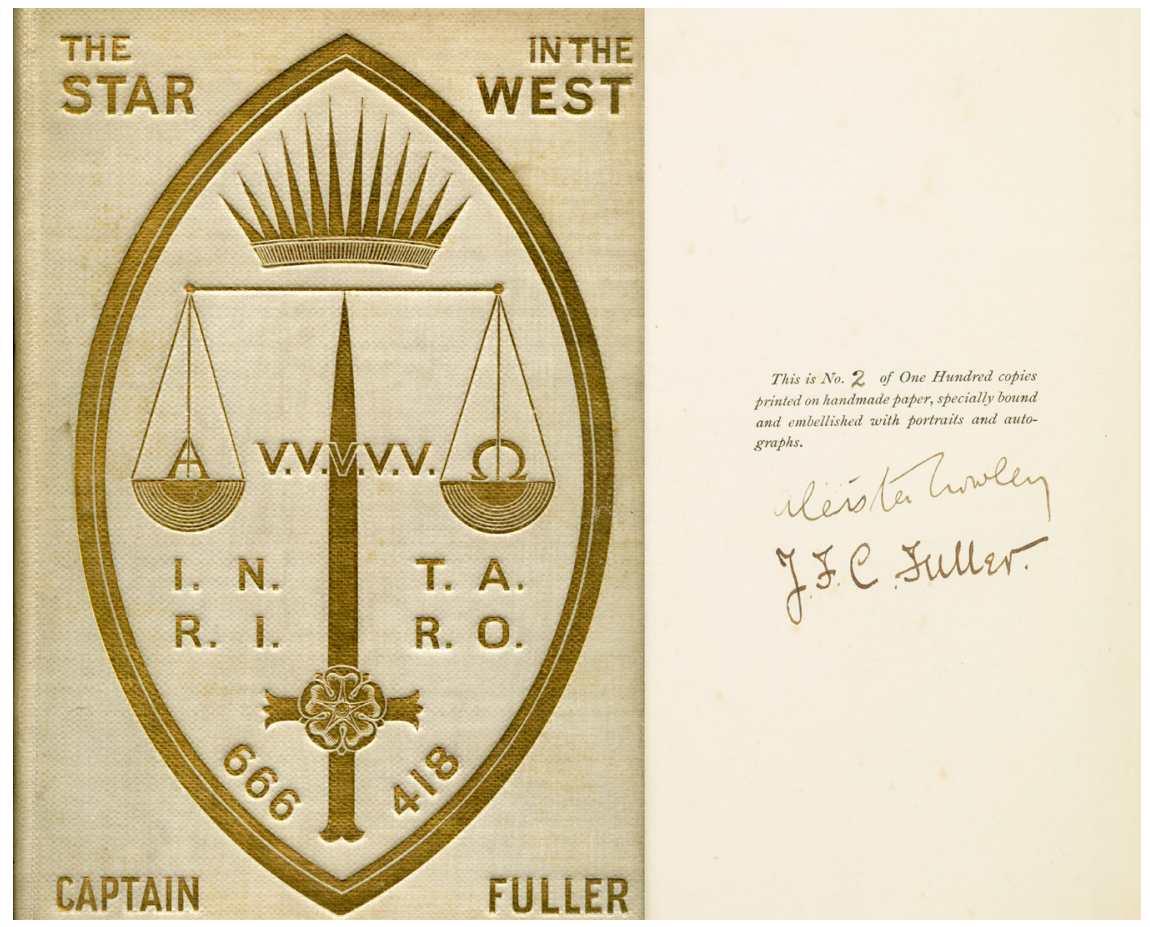

Front cover and inscription leaf from Capt. J. F. C. Fuller, The Star in the West: A Critical Essay Upon the Works of Aleister Crowley (New York, 1907) No. 2 of 100 copies. Autograph signed by Aleister Crowley and J. F. C. Fuller. Inscription: "To my lazy rosebud. 20th July $1907^{\prime \prime}$

While the Crowley material is important, Sloane, Cameron, and others recognized that Fuller's uniqueness and place in military history if not the history of Europe between the wars was significant. Sloan notes:

Going back to General Fuller. . . I find his books a curious mixture of violent partisanship for one set of ideas and an 
extraordinarily fresh and irreverent approach to orthodoxies. Speaking generally, he may be made as a historian, but as a military man he was pretty right all along the line and certainly from the Battle of Cambrai to the collapse of Hitler, he managed to be more right than anybody else with the possible exception of Winston Churchill on whom, I suspect, he had rather more personal influence than either man will ever publicly declare. ${ }^{38}$

Rutgers clearly saw the importance of J. F. C. Fuller though the acquisition of his papers did not correspond to any articulated collecting policy. This situation was common with the appraisal, selection, and acquisition of archival records in this time period. Sloane knew that preserving historical documentation of this nature would be crucial for scholarly inquiry, he also was fashioning the Rutgers University Press as a premier publisher of scholarly works of military history. In light of these considerations, the acquisition seemed appropriate. Colleagues at the time, however, did express some dismay as Sloane conveyed to the Dean of the Graduate School of Library Service, Neal Harlow.

I think I should add that although General Fuller's military and writing career went back to the World Wars all his papers and books were bombed out in both wars and what remains is fragmentary and doesn't cover the whole spectrum of his long and influential life. Lloyd's informed me that the British Commission which passes on the export of library and other materials, expressed real regret at seeing these papers go out of the country, but I am no judge of that situation. ${ }^{39}$

Today I think historians and archivists in the UK would have made sure his papers stayed in the UK, where other J. F. C. Fuller papers reside at the Liddell Hart Centre for Military Archives at King's College, London, in the Public Records Office, and at the Staff College Camberley. ${ }^{40}$ Nonetheless, what nobody at the time identified was the importance of the Crowley-related materials in the Rutgers acquisition, which provided the impetus for the colloquium held in New Brunswick in 2014. Aleister Crowley was arguably the most celebrated, or derided, occultist in the twentieth century, a role that was popularized in the late 1960s and early 1970s. Several scholars and manuscript repositories have collected 
Crowley with an eye towards serious historical and historiographical study of Western esotericism, which has significantly increased in the last fifteen years. While the related items in the Fuller collection are important, they take their place in a larger context of Crowley archives. Among the most notable are: the Warburg Institute at the University of London, The Harry Ransom Center at the University of Texas at Austin, the Lilly Library at Indiana University, and the Special Collections Center at Syracuse University.

\section{Analysis of the Fairweather Collection}

While the Occult has captured the popular imagination since the Romantic Era, we also see the serious study of the Occult within the traditional academic disciplines takes many forms and represents many fields of inquiry including Middle Eastern Studies, History, Religion, Folklore, Mathematics, Chemistry, Astronomy, Literature, and even the study of the esoteric sciences is now its own academic discipline. I think this reveals the importance and relative abundance of the works in SC/UA's collection. If the study of the occult and esoteric sciences is a field that examines the larger relationships between the history of science, literature, folklore and religion it may be that the works are not so rare. The "Occult," by definition, suggests the mysterious, hidden, or secret, and the topics represented in the Fairweather collection are far from it. It turns out than many of the titles collected by Fairweather exist in relative abundance. A comparative analysis of the holdings of Rutgers University Libraries and the Fairweather Collection reveals that most of our titles are also held by many libraries in North America and Europe. It seems a popular area to collect. Among the libraries with significant or duplicate holdings of our titles include: Princeton, Harvard, Yale, University of Pennsylvania, New York Public Library, Columbia, Cornell, the College of Physicians (Philadelphia), University of Delaware, University of Chicago, National Library of Medicine, Library of Congress and in Europe Oxford, the British Library, and the Bibliotèque Nationale de France. ${ }^{41}$

Of particular note are several libraries in with significant or specific collecting areas in the occult and esoteric sciences: in North America-Yale University, New York Public Library, the University of Illinois, and the University of Delaware; in the UK-the Senate House Library, Wellcome Library, and Oxford University; and in Australia, Monash University. Perhaps too, inspired by the 
popular imagination of witchcraft, magic, and the occult, in the last five years there has been a burst of exhibitions regarding the occult which focus on collections held by libraries and museums worldwide. $^{42}$

Such "abundance" I think is partially the result of the popularity of the topics in their time as well as in ours, specifically astrology and prophecy, and their role in early- modern-period printing and publishing represented by the phenomenal success of writers like William Lilly, Nicholas Culpeper and later, in the nineteenth century, Raphael and Zadkiel. William Lilly's publications, specifically his annual almanac first published in 1644 , were a resounding success and sales were very high by 1649 reaching 30,000 copies. Both Lilly and Nicholas Culpeper shared the conviction that astrology and physic (medicine) should be widely available to the public in the vernacular. From the perspective the study of early printing and the publishing "industry" and in terms of consumption and popular culture, the Fairweather Collection offers significant source material. Despite individual titles represented in other rare book repositories, Rutgers offers a good cross-sampling of pre-twentieth-century books dealing largely with astrology and alchemy with a focus on astrology and medical astrology in the seventeenth and nineteenth centuries. Taken as a whole, the collection affords the student and scholar alike, an exploration of various topics in one concentrated and comprehensive body of knowledge.

\section{Standout Titles from the Fairweather Collection}

Among the books from the Fairweather collection are a few unique titles-some represent the only North American holdings of the book, others represent topics of unusual interest or possess outstanding aesthetic or artifactual value, and others represent a deep or comprehensive coverage of a topic or author. The collection consists predominantly of books on astrology and prophecyjudicial, natal, and natural astrology - and the works of William Lilly, Nicholas Culpeper, Claude Dariot, and Antoine Mizauld are very well represented as well as John Gadbury and Nostradamus. ${ }^{43}$ Of the approximately 345 titles in the Fairweather collection its primary categories include astronomy and cosmology (15); astrology and prophecy (105); medical astrology/medicine and botany/materia medica (60); chemistry/alchemy (15); witchcraft, magic, and demons (30); almanacs (9); Egypt and the Near 
East (10). Taken together the section of the collection covering astronomy and astrology (including medical astrology and materia medica) comprises approximately two-thirds of the collection. Witchcraft and magic follow, then chemistry and alchemy, Egypt and the Near East, etc.

While held by other libraries in the United States and Europe, the only incunabula in the collection bears mentionAvienus, Rufius Festus Hic codex Auienii co[n]tinet epigra[m]ma ... [Works] (1488) which is bound with two other works, Bartolomeo Crotti, Epigrammatum elegiarumaque libellus (1500), and Jakob Schoenheintz Apologia astrologie (1502). This volume includes a collection of astronomical and geographical works by Avienus, including his Arati Phaenomena, as well as two other adaptations of Aratus's Phaenomena by Germanicus Caesar and Cicero, Avienus's Latin version of Orbis terrae description by Dionysius Periegetes, Ora maritima by Avienus and the Liber medicinalis by Serenus Sammonicus. Rufius Festus Avienus was a Latin poet of the fourth century $\mathrm{CE}$ who wrote in hexameter verse a translation of the Phaenomena of Aratus, a geography based upon Dionysins Periegetes (Descriptio Orbis Terrarum); and another geographical piece (Ora Maritima) in iambics, describing the coasts of the Mediterranean, Black, and Caspian seas. It is in the Avienus where the first recorded use of the incantation "Abracadabra" occurs.

Other works of note (listed in chronological order) include:

1. Hyginus, C. Julius. 1535. C. Iulii Hygini Augusti liberti Fabularum liber [Fabulae] (held by multiple libraries)

The authorship of this work is disputed, but attributed to first century writer C. Julius Hyginus the director of the Palatine Library of Alexandria. It is a beautifully illustrated treatise on mythological legends and mythological genealogies.

2. Ficino, Marsilio. 1548. Marsilii Ficini Florentini ... De vita libri tres [De triplici vita]

(held by multiple libraries)

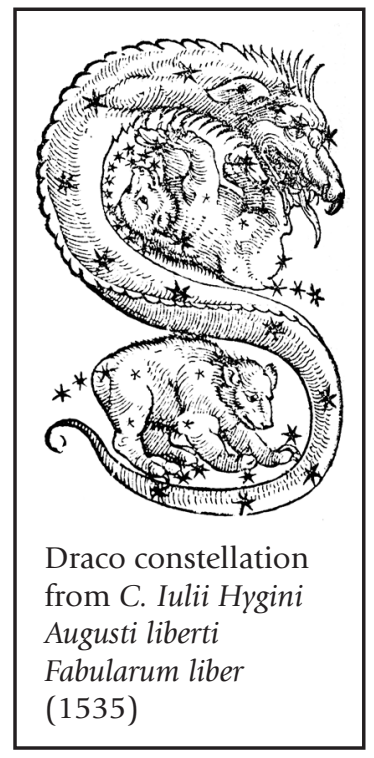


Marsilio Ficino (1433-1499) was one of the most influential humanist philosophers of the early Italian Renaissance, an astrologer, a reviver of Neoplatonism and the first translator of Plato's complete extant works into Latin. His Florentine Academy, an attempt to revive Plato's school, had enormous influence on the direction of the Italian Renaissance and the development of European philosophy. The De vita libri tres (Three Books on Life) was written in the years 1480-1489, then published in 1489, and was consistently in print through the middle of the seventeenth century. De vita is a combination of philosophy, medicine, "natural magic" and astrology.

3. Dariot, Claude. 1557. Ad astrorum iudicia facilis introduction Rutgers holds one of two of the only North American copies of this work.

4. Mizauld, Antoine. 1564. Noua et mira artificia comparandorum fructuum, olerum, radicum, vuarum ... quae.

Rutgers holds the only North American copy of this work. The Fairweather accession includes many versions of Mizauld's works. Antoine Mizauld (1510-1578) was a French doctor, astrologer, and naturalist whose work covers a vast expanse of topics including medicine, astrology, and botany. He became a professor of medicine in Paris. Under Oronce Fine he was introduced to astrology and astronomy, interpreting it as a branch of medicine.

5. Aratus, Solensis. 1569. Arati Solensis Phoenomena et prognostica (held by multiple libraries)

Aratus was a Greek poet who lived from around 315/310-240 BCE. His work has been lost to us in Greek, but numerous Latin translation of his

Phoenomena survived, such as the one contained

DE SATVRNO.

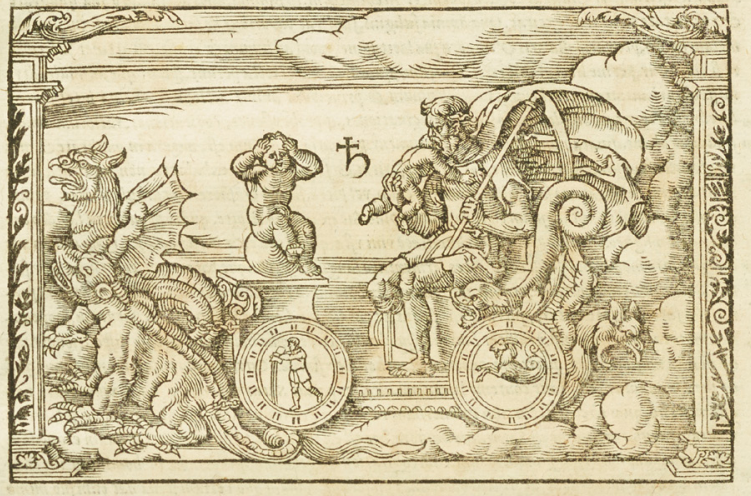

De Saturno (Saturn on a chariot eating children) from Arati Solensis Phenomena et prognostica $(1569,1570)$ 
in this book. The book contains numerous woodcuts

6. Giuntini, Francesco. 1583. Speculum astrologiae, vniversam mathematicam scientam, in certas classes digestam, (held by multiple libraries) Francesco Giuntini (Junctinius) (c. 1523-1590?), was a Florentine, Carmelite Friar, theologian, doctor, mathematician, and astrologer. His massive Speculum astrologiae (in two volumes), contains Greek and Latin versions of Ptolemy's Tetrabiblios, commentary on the work, his own treatises on astrological theory, nativity charts of famous men, and commentary on astronomical topics. Giuntini defines astronomy simply as the study of the heavenly bodies

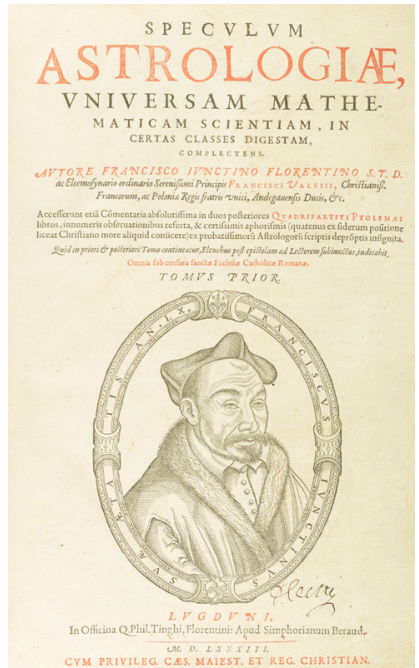

Title page of Franceso Giuntini, Speculum astrologiae, vniversam mathematicam scientam. . (1583) and their motion.

7. Cattan, Christoforo. 1591. The Geomancie of Maister Christopher Cattan gentlemanRutgers University Libraries holds one of only two copies in North America.

8. Goclenius, Rudolph. 1609. Vranoscopiae, chiroscopiae, metoposcopiae, et ophthalmoscopiae, comtemplatio Rutgers University Libraries holds the only copy of this book.

9. Morgard, Noel Leon. 1619. Le manifeste et prophetie de Morgard spectacular es causes seconds Rutgers University Libraries holds one of only two copies in North America.

10. Finella, Filippo. 1634. Della vertu occulte delle vipere

Rutgers University Libraries holds the only copy in North America.

11. Lilly, William, The starry messenger, or, an interpretation of that strange apparition of three suns seene in London, 19. Novem.

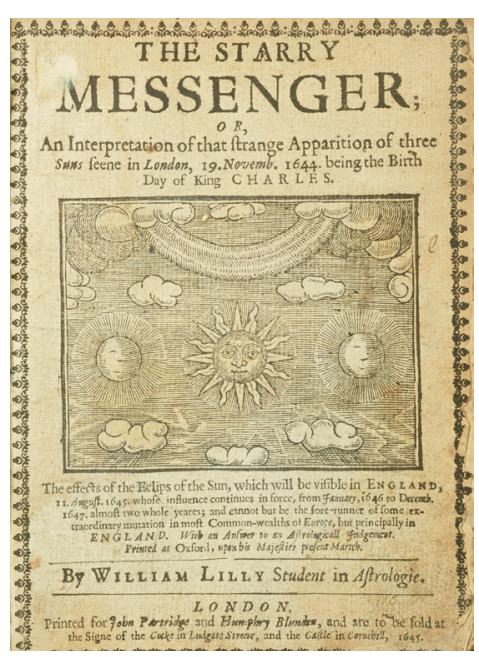

Title page of William Lilly, The starry messenger.. (1645) 
1644, being the birth day of King Charles: the effects of the eclips of the sun which will be visible in England, 11. August. 1645 . . . (London, 1645)

Lilly, William, Christian Astrology: modestly treated of in three books ... (London, 1659)

(held by multiple libraries)

12. Les vrayes centuries de Me. Michel Nostradamus. 1652.

While there are many versions, editions and translations, Rutgers University Libraries holds the only North American copy of this edition.

13. Indagine, Johannes ab. 1662. La chiromance et phisionomie par le regard des membres de l'homme

Rutgers holds the only North American copy of this work.

14. Casaubon, Meric. 1669. Of credulity and incredulity, in things natural, civil, and divine. Rutgers holds the only copy of this work.

15. Pignoria,

Lorenzo. 1670.

Laurentij Pignorij

Patavini Mensa

Isiaca.

While held in multiple libraries, this volume is not only in excellent condition and represents some of the earliest work in Egyptology, but it includes large folding plates of this edition engraved by the Venetian engraver and publisher Giacomo Franco

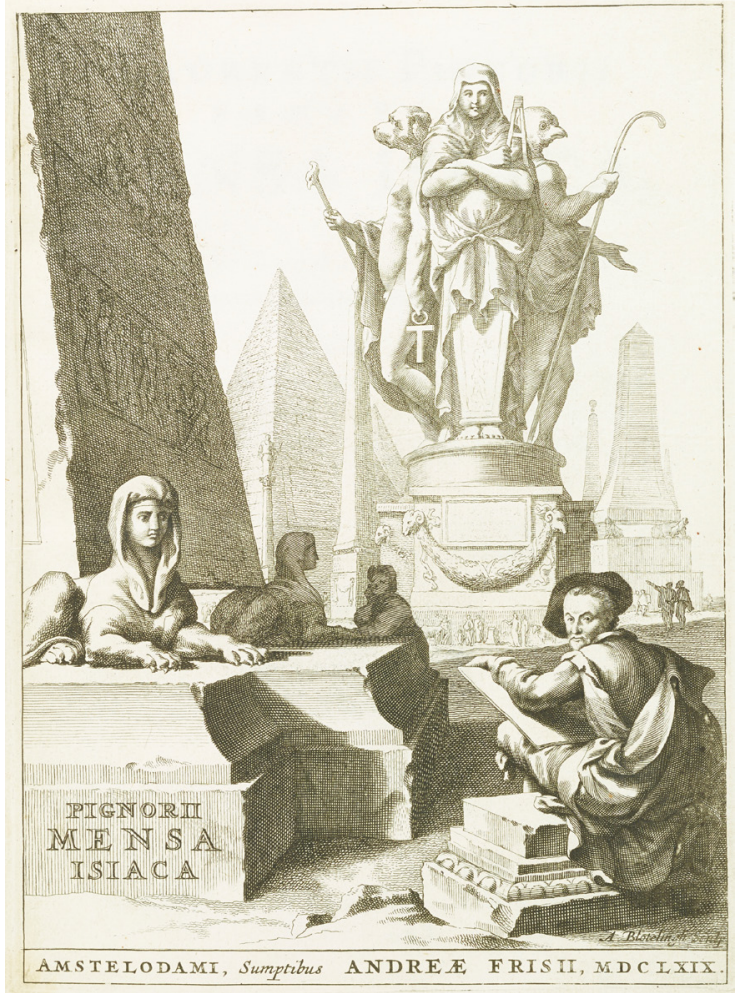

Frontispiece of Lorenzo Pignoria, Laurentij Pignorij Patavini Mensa Isiaca... (1670) in 1600 to replicate the various parts of the Table, and were included, 
variously assembled and folded, in a handful of copies of the first edition, published by Franco in 1605. In later editions the large woodcuts were reproduced as copperplate engravings.

16. Culpeper, Nicholas. Culpeper's semeiotica uranica, or, An astrological judgement of diseases, from the decumbiture of the sick, much enlarged. . . wherein is laid down the way and manner of finding out the cause, change, ad end of the disease. . and of life and death by the good or evil position of the moon at the time of the patients lying down. . .(London, 1671)

(held by multiple libraries)

17. Scarabicio, Sebastiano. 1678. De lapidis concretione in homine... Rutgers holds one of only two copies in North America

18. Scarabicio, Sebastiano. 1678 Historia bouini cerebri in lapidem mutate

Rutgers holds the only copy in North America.

19. Parker, George. 1705. The royal speculum for the year of our Lord 1705 Rutgers holds the only copy.

20. DuPlessis, Clavier. 1780. Mytho-hermetisches Archiv.

Rutgers holds the only copy in North America.

21. Souci, Antoine. 1790. Almanac historique, nomme Le messager boiteux

Rutgers holds one of two copies in North America.

22. La cle d'or, ou, l'art de gagner a la loterie. 1816.

Rutgers holds the only copy.

23. Saint-Martin, J. (Jean). 1822. Notice sur le zodiac de Denderah Karl, Landgraf zu Hessen-Kassel. 1824. La pierre zodiacale du temple de Denderah.

While multiple libraries hold these two works on the Temple of Denderah, they are representative of the renewed interest in Egypt in early nineteenth-century Europe, and coincide (particularly Saint-Martin) with the discovery and translation of the Rosetta Stone.

24. Zadkiel. 1831. The herald of astrology for the year 1832.

This title represents the popularity of astrology in the nineteenth century. Although other libraries hold many copies of titles of Raphael and Zadkiel, Rutgers hold the only copy of this year and edition in North America.

25. Raphael. 1841. The familiar astrologer

Exemplary of mid-nineteenth-century publishing of astrology titles and includes excellent color illustrations (see next page). (held by multiple libraries) 


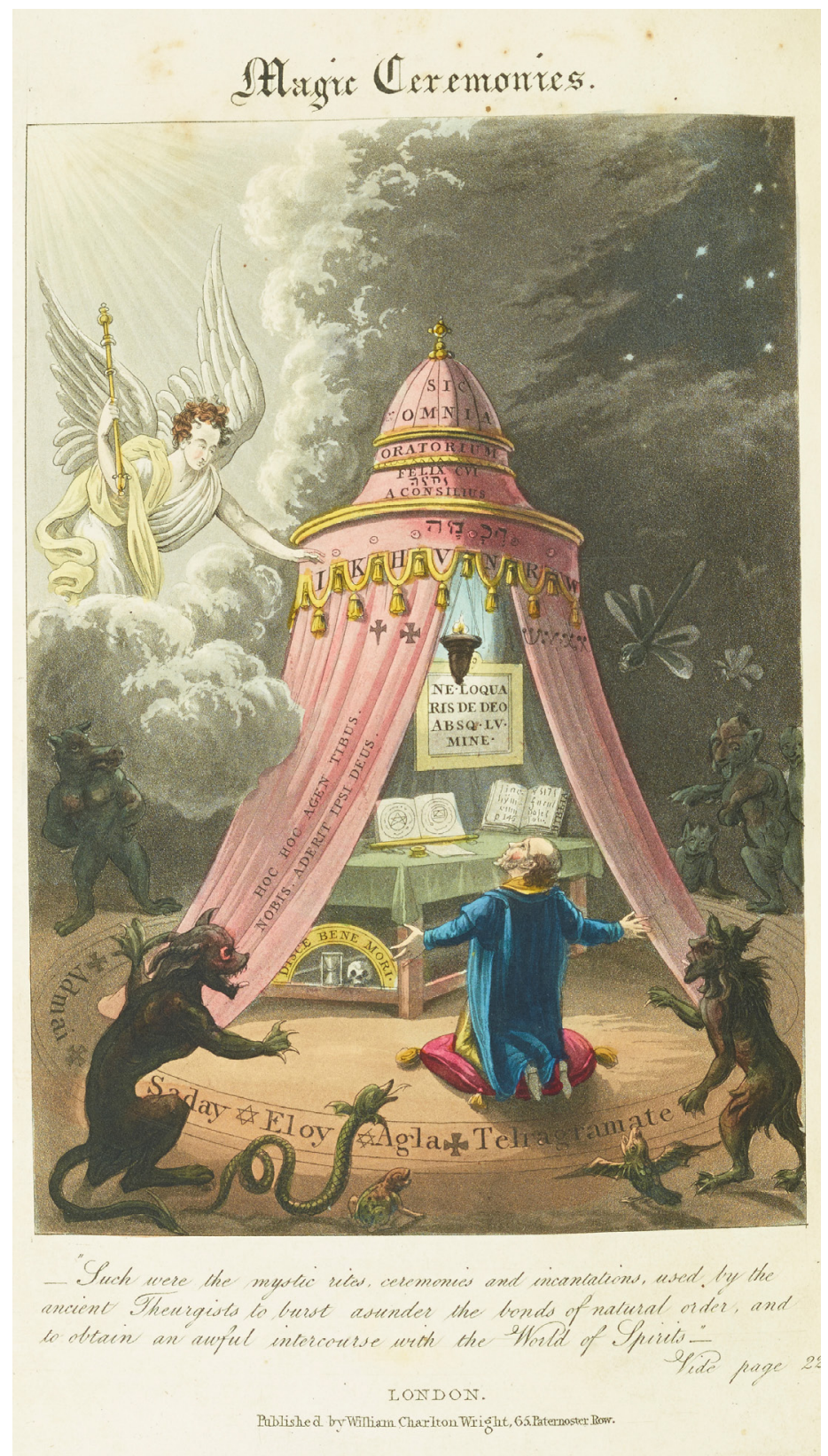

Color plate from The astrologer of the nineteenth century, or, Compendium of astrology, geomancy, and occult philosophy ... ( London, 1825) An example of the revival and popularity of astrology and esoteric sciences in the $19^{\text {th }}$ century, this periodical covered multiple topics such as prediction, necromancy, summoning spirits, and apparitions. It featured colorful plates, which became characteristic of almanacs and astrology periodicals during the century. 
26. Flamel, Hortensius. 1844. El libro negro.

Eliphas Levi, born Alphonse Louis Constant (1810-1875), was a French occult author and ceremonial magician. He was a primary figure in the nineteenth-century French occult revival. His early works appeared under a variety of pseudonyms. A book of spells that include how to: protect a house from the plague and lightning, how to cure feet that are worn out from too much walking, to cure piles or hemorrhoids, to repel flies from the house, to relieve night visions, to have happy dreams, to be lucky in one's endeavors, to make a man impotent, to make a barren woman fertile, to conserve a woman's beauty, and to make it so a woman is happy with her spouse.

Rutgers holds the only copy in North America.

27. Bellanger, Augustin-Rene. 1854. Le magnetism

Rutgers holds the only copy in North America.

28. Le Voile d'Isis. (1890-1898)

Under the organization "Group Independent d'etudes esoteriques de Paris" (1890-1935), Le Voile d'Isis was an esoteric journal published in Paris dedicated to occultism and esotericism for the purpose of fostering "études esoterieuqes, psychiqyes, et divinatoirs." Articles in the journal covered diverse topics on what is easily recognizable as "occultism" to our contemporary eye. In addition, the advertisements and announcements for exhibitions and public lectures in the magazine illuminate the popularity of the occult which had seen a full-fledged revival in fin-de-siècle Europe and the United States.

(held by multiple libraries)

29. Bosc, Ernest. 1897. Isis devoilee, ou, l'egyptologie sacree Rutgers holds the only copy in North America.

30. Sepher ha-Zohar [Zohar. French]. 1906.

Rutgers holds the only copy in North America. 


\section{NOTES}

1. Erika Gorder, Unheard of Curiosities: An Exhibition of Rare Books on the Occult and Esoteric Sciences. February 2014. New Brunswick, N.J.: Rutgers University Libraries Special Collections and University Archives, 2014. Online version available at: http://dx.doi.org/ doi:10.7282/T3NS0T53

2. Gary Lachman, A Dark Muse: A History of the Occult. (New York: Thunder's Mouth Press, 2005), 14 First published in the UK by Dedalus, 2003.

3. For a general overview see Dr. Anthony Aveni, Professor of Astronomy and Anthropology at Colgate University Behind the Crystal Ball: Magic, Science, and the Occult from Antiquity through the New Age (Boulder, CO: University Press of Colorado, 2002); works on related topics include H. Darrel Rutkin, "Galileo Astrologer: Astrology and Mathematical Practice in the Late- Sixteenth and Early-Seventeenth Centuries, Galileaana, II, 2005 pp. 107-143; Dan Burton and David Grandy, Magic, Mystery, and Science: The Occult in Western Civilization (Bloomington, IN: Indiana University Press, 2004); Charles Webster From Paracelcus to Newton: Magic and the Making of Modern Science, The Eddinton Memorial Lectures Delivered at Cambridge University November 1980, (Cambridge: Cambridge University Press, 1983); William R. Newman, Atoms and Alchemy: Chymistry and the Experimental Origins of the Scientific Revolution, (Chicago: Chicago University Press, 2006)

4. The study of ancient Egypt began with the Egyptians themselves in the Ptolemaic period (305-30 BCE) and extended to Greece and Rome; Western "Egyptomania" begins in the mid-nineteenth century and flourishes in the 1920s.

5. Additional examples of current scholarship include Tara Nummedal Alchemy and Authority in the Holy Roman Empire (Chicago: Chicago University Press, 2007); Kocku Von Stackrad Locations of Knowledge in Medieval and Early Modern Europe: Esoteric Discourse and Western Identities (Leiden and Boston: Brill, 2010); Gordan Djurdjevic, India and the Occult: The Influence of South Asian Spirituality on Modern Occultism (Palgrave Macmillan, 2014).

6. University Programs or Departments: Center for History of Hermetic Philosophy and Related Currents, University of Amsterdam, Netherlands; Exeter Centre for the Study of Esotericism, Exeter University, United Kingdom; Sophia Center for the Study of Cosmology in Culture \& MA in Cultural Astronomy and Astrology, University of Wales Trinity Saint David, United Kingdom. Chairs for the study of esotericism also exist at the Ecole Pratique des Hautes 
Etudes in Paris, France and University of Gothenburg in Stockholm, Sweden.

Academic Associations: European Society for the Study of Western Esotericism (ESSWE).The ESSWE is an affiliated society of the International Association for the History of Religions (IAHR) and a related scholarly organization of the American Academy of Religion (AAR); Association for the Study of Esotericism; American Academy of Religion--Western Esotericism Group; Esotericism and Mysticism group of the Society of Biblical Literature.

Scholarly Journals: Esoterica; Aries: Journal for the Study of Western Esotericism; Magic, Ritual, and Witchcraft. (University of Pennsylvania Press); Culture and Cosmos (University of Wales); The Pomegranate: The International Journal of Pagan Studies; Conferences: The Healing Arts Across the Mediterranean: Communities, Knowledge and Practices, March 2014, Rutgers University Medieval Studies, available at http://medieval-studies.rutgers.edu/events/conferences/icalrepeat. detail/2014/03/28/46/-/the-healing-arts-across-the-mediterraneancommunities-knowledge-and-practices; Symposium: Science and the Occult in European History, Purdue University, available at http:// catalinaghionea.net/Science and Occult Symposium last version. pdf; Characterizing Astrology in the Medieval Islamic World, May 1214, 2015. University of Chicago-Divinity; ASE Fifth International Conference, June 19-22, 2014, at Colgate University, Association for the Study of Esotericism.

7. Fernanda Perrone, in exhibition catalog Unheard-of Curiosities, 6.

8. Clement Fairweather files. Rutgers University Faculty Biographical Files (R-Bio Faculty) and Rutgers University Alumni Biographical Files (R-Bio Alumni), Box 279.

9. Clement W. Fairweather, English Sermon Wit, 1550-1660. Ph.D Dissertation. Princeton University: 1942.

10. Unidentified. Remarks on the Occasion of the Retirement of Clement Fairweather, undated. [ca. 1984]. Rutgers University Faculty Biographical Files (R-Bio Faculty).

11. Ibid.

12. Ibid.

13. Ibid. I am not sure where the speaker got this quote but I assume either personal letter or departmental correspondence/report.

14. Ibid.

15. Ibid.

16. Ibid.

17. Ibid. 
18. H.P. Lovecraft (Howard Phillips) was the author of stories including: "Colour Out of Space," "The Case of Charles Dexter Ward," "At the Mountains of Madness," "The Dream-Quest of Unknown Kadath," "The Doom that Came to Sarnath," "The Cats of Ulthar," among many others.

19. H. P. Lovecraft, Supernatural Horror in Literature (with an introduction by August Derleth). (New York: Ben Abramson Publisher, 1945).

20. "Reforming the Kidnaped [sic] Child Crown Prince of the Most Notorious Free-Love Cult: The Very Strange Case of 'Beast No. 2, Age 7." Springfield Republican, December 7, 1924. While most of these sensationalized articles are considered inaccurate by Crowley scholars, there is some basis of fact. Hans (Hansi) Hammond's mother, Leah Hersig, took part in the founding of the Abbey of Thelema with Crowley in Cefalu, Italy and was Crowley's lover, part of her role as a "Scarlet Woman," taking the name Alostrael.

21. Aleister Crowley, Book Four/by Frater Perdurabo and Soror Virakam. (London, 1911)

22. The Ordo Templi Orientis (O.T.O) the Order of Oriental Templars, or Order of the Temple of the East, is an international esoteric group and religious organization. The order centers on Crowley's The Book of the Law, a system of magic featuring "Thelema" or will, and its basic admonition, "Do what thou will shall be the whole of the Law." Originally founded in Germany the early twentieth century, Crowley became involved in 1912 and later in life focused on building the O.T.O until his death in 1947.

23. Colloquium: The Soldier and the Seer: J. F. C. Fuller, Aleister Crowley, and the British Occult Revival. June 23, 2014. Held by Rutgers University Libraries in association with Academia Ordo Templi Orientis.

Program:

Erika B. Gorder, (Rutgers University Libraries) "Inadvertently Occult: Rutgers University, the Fairweather Rare Book Collection, and the J. F. C. Fuller Papers.

Henrik Bogdan, (University of Gothenburg) "The J. F. C. Fuller and Aleister Crowley Correspondence: A Story of an Unlikely Friendship."

Gordan Djurdjevic (Simon Fraser University; University of British Columbia), "Yoga and Buddhism in The Temple of Solomon the King" J. F. C. Fuller's Account of Aleister Crowley's Engagement with Asian Spirituality."

Richard Kaczynski, (Yale University; University of Detroit Mercy)“J.F.C. Fuller's Continuing Interest in the Occult after 1911." 
Christian Giudice, (University of Gothenburg) "The Beast and the Black Shirt: J. F C. Fuller's ties to the British Union of Fascists and the German N.S.D.A.P"

Robert Stein (SUNY Buffalo, emeritus), "Crowley, the Alphabet and the Significance of "Liber 231."

William Breeze, (Ordo Templi Orientis Archives), "The Beast in the Academy: The Relegitimization of Aleister Crowley and the Importance of his Manuscripts as Primary Sources."

24. For a thorough biography of Fuller see Anthony John Trythall, 'Boney' Fuller: Soldier, Strategist, and Writer, 1878-1966. (New Brunswick, NJ: Rutgers University Press, 1977).

25. J.F.C. Fuller, Machine Warfare: An Enquiry into the Influence of Mechanics on the Art of War (London: Hutchinson, 1942), p. 14 as quoted in Trythall, p. 205.

26. George Cecil Jones was a chemist and a member of the Order of the Golden Dawn and met Aleister Crowley in 1898. Later he was a cofounder with Crowley and Fuller of the magickal order A. ' A. $\cdot$. in 1909. Jones vs. The Looking Glass was a libel case that arose as a result of the magazine's coverage of the staging of the A. $\cdot$.A. $\cdot$. "Rites of Eleusis" at Caxton Hall in Westminster in October and November 1910. The event garnered much attention in the press. The Looking Glass named both Cecil Jones and Allan Bennett as close friends of Crowley and more than insinuated at a homosexual relationship between Bennett and Crowley. During the case, controversy arose regarding Crowley's sexuality although he was not a party to the case. Only Jones chose to sue. Crowley did not volunteer to give evidence, but Fuller did so on behalf of Jones who ultimately lost the case.

27. Interest in the theory and practice of Yoga and Asian spiritual traditions marked the time period and influence on men of Imperial Britain stationed in the Near East.

28. Star in the West: a critical essay upon the works of Aleister Crowley (Walter Scott Publishing Co., London, 1907); Other books by Fuller include: Yoga: A Study of the Mystical Philosophy of the Brahmins and Buddhists (W. Rider, London, 1925); Atlantis, America and the Future. (London, Kegan Paul, 1925); The Foundations of the Science of War. (London, Hutchinson, 1926); The Generalship of Ulysses S. Grant (Murray, London, 1929); Grant \& Lee: A Study in Personality and Generalship (Eyre \& Spottiswoode, London, 1933); Memoirs of an Unconventional Soldier (Nicholson \& Watson, London, 1936); The First of the League Wars: A study of the Abyssinian War, Its Lessons and Omens (Eyre and Spottiswoode, London, 1936); The Secret Wisdom of the Qabalah: A study in Jewish mystical thought (W. Rider \& Co., 
London, 1937); Armament and History: The Influence of Armament on History from the Dawn of Classical Warfare to the end of the Second World War (C. Scribner's Sons, London, 1945).

29. William Sloane was Director of the Rutgers University Press from 1955-1974. Prior to his arrival at Rutgers, he was an editor at Farrar \& Rinehart, vice president of Henry Holt \& Company, founder of his own publishing house, William Sloane Associates, Inc., and editorial director of Funk \& Wagnall's Company. A graduate of Princeton University (1929), Sloane was an author of fantasy and science fiction literature best known for his novel To Walk the Night (1937). His papers reside at Princeton University Department of Rare Books and Special Collections, Manuscripts Division.

30. William Sloane to J. F. C. Fuller, letter, March 22, 1962. J. F. C. Fuller Papers, (MC 1250) Box 3. Special Collections and University Archives, Rutgers University Libraries (referred to hereafter as "Fuller Papers (MC 1250)").

31. J. F. C. Fuller to William Sloane, letter, April 18, 1962. Fuller Papers, (MC 1250) Box 3.

32. J. F. C. Fuller to William Sloane, letter, December 12, 1962. Fuller Papers, (MC 1250) Box 3.

33. Donald Cameron was University Librarian from 1944 to 1966 . He came to Rutgers in 1929 as a member of the English Department faculty.

34. Donald Cameron to William Sloane, letter, September 21, 1964. Fuller Papers, (MC 1250) Box 3.

35. For more details on the diaries see Donald Sinclair, Guide to Diaries and Journals in Special Collections and University Archives, Rutgers University Libraries. New Brunswick [N.J.]: Archibald Stevens Alexander Library, Rutgers University, 1980. Available online at http://dx.doi.org/doi:10.7282/T3WQ01RP.

36. The Iraq Levies were the first Iraqi military forces established by the British in British controlled Iraq.

37. William Edmund Ironside to J. F. C. Fuller, letter, March 14, 1929. Fuller Papers, (MC 1250) Box 2.

38. William Sloane to Donald Cameron, letter, September 23, 1964. Fuller Papers, (MC 1250) Box 3.

39. William Sloane to Neal Harlow, July 29, 1968. Fuller Papers, (MC 1250) Box 3.

40. The other J. F. C. Fuller papers reside in the Liddell Hart Military Archives (LMHA), Kings College London (GB0099 KCLMA Fuller) 
and is contained in 12 boxes that span the years 1897-1966. These papers were presented by Fuller in 1965. The correspondents and topics represented are very similar to the contents of the RUL accession and also contain papers related to the occult, notably letters from Aleister Crowley, 1905-1924; Also at the LHMA the Papers of Sir Basil Liddell Hart include correspondence with Fuller, 1920-1966; the Royal Armoured Corps and Royal Tank Regiment Museum in Bovington Dorset, United Kingdom holds his diary, 1914-1918; other repositories with Fuller papers include the Churchill Archives Centre, Cambridge University; The India Office Records at the British Library; and the papers of Karl Van Weiganei at the Hoover Institution (Stanford, USA).

41. Author's search of each title in the Fairweather collection, approximately 345 titles, in WorldCat between December 2014 and January 2015.

42. Occult Science \& Philosophy of the Renaissance (Exhibition and some permanent collection). Louisiana State University, Hill Memorial Library Special Collections.

Complement to traveling exhibition, "Harry Potter's World: Renaissance Science, Magic and Medicine," sponsored by the National Library of Medicine and hosted by LSU's Middleton Library. Drawn primarily from the Rare Book, Mcllhenny, and Rhoades Collections, the items included here reflect the library's strong holdings in early-modern science, religion, and philosophy. Available at http://exhibitions.blogs.lib.lsu.edu/?p=1257

The Occult (Exhibition and Permanent Collection) Monash University Rare Book Collection, Melbourne, Australia. An Exhibition of material from the Monash University Library Rare Book Collection displays material from the Rare Book Collection covering the fields of witchcraft, spiritualism, alchemy and mesmerism. Objects are on display as well as books. Available at http://monash.edu/library/collections/exhibitions/occult/xocccat. $\underline{\mathrm{html}}$

Occult Sciences and Parapsychology collection. New York Public Library. New York, NY. The New York Public Library has an extensive collection of materials on the occult. The General Research Division collects a wide range of topics including esoteric magic (as opposed to stage magic, which is collected by the New York Public Library for the Performing Arts), spiritualism and witchcraft. There are particularly strong collections on divination and theosophy. The Science, Industry and Business Library collects materials on alchemy and flying saucers. Books on oriental mysticism and yoga are collected by the Asian and Middle Eastern Division. The Slavic and Baltic Division collects, in the original language, the works of 
Russian mystics, such as H. P. Blavatsky, and the Schomburg Center for Research in Black Culture collects titles on voodoo, and related topics. For more information, see http://www.nypl.org/node/5640

The Perfect Medium: Photography and the Occult. Metropolitan Museum of Art. New York, NY. (Exhibition). For more information, see at http://www.metmuseum.org/about-the-museum/press-room/ exhibitions/2005/the-perfect-medium-photography-and-the-occult

The Merten J. Mandeville Collection in the Occult Sciences. University of Illinois-Urbana Champaign. (Exhibition and Permanent Collection). This collection of approximately 16,000 volumes is supported by an endowment established by the late Merten J. Mandeville, a Professor of Management at UIUC. More information available at http://www.library.illinois.edu/sshel/ specialcollections/mandeville/mandgui.html

Perfecting Nature: Medicine, Metallurgy and Mysticism Alchemical Texts from Special Collections, University of Delaware (Exhibition and Permanent Collection). The University of Delaware Library has announced "Perfecting Nature: Medicine, Metallurgy and Mysticism Alchemical Texts from Special Collections," an exhibition of alchemical books and manuscripts from the sixteenth, seventeenth and eighteenth centuries." More information available at http:// www.lib.udel.edu/ud/spec/exhibits/alchemy/index.html

Occultism and Science in the Early Modern World: An Exhibit of Rare Books (Exhibition and permanent collections). Washington University School of Medicine in St. Louis, Bernard Becker Medical Library Glaser Gallery. The Becker Medical Library's Archives and Rare Books division is currently hosting an exhibit of its rare books that examines the early modern relationship between science and magic.

University of Pennsylvania Manuscript Collection. The Rare Book \& Manuscript Library holds a variety of codex manuscripts and archival documents relating to several branches of scientific study and to the occult. The Edgar Fahs Smith Memorial Collection contains more than sixty manuscript items, as well as a variety of miscellaneous manuscripts, and many printed works concerned with the history of chemistry and alchemy. More information available at http://www. library.upenn.edu/collections/rbm/mss/.

Book of Secrets: Alchemy and the European Imagination, 1500-2000, January 20-April 18, 2009. Yale University. Beinecke Rare Book and Manuscript Library. Yale's collection of alchemical literature began with a donation from Bishop George Berkeley and was supplemented by a gift to Yale in 1965 of Mary Conover Mellon's collection of alchemical books and manuscripts. Beyond older manuscripts, the Beinecke also contains other, more contemporary books, manuscripts, and documents related to alchemy, magic, the 
imaginary, and the supernatural. More information available at http://beineckeearlymodern.library.yale.edu/2009/02/26/book-ofsecrets-alchemy-and-the-european-imagination-1500-2000-2/

Magical Books: From the Middle Ages to Middle-earth An exhibition at the Bodleian Library, 23 May-27 October 2013. Oxford University. Bodleian Library. More information available at http://www. bodleian.ox.ac.uk/whats-on/online/magical-books

43. Prophecy involves messages of divine or spiritual inspiration through a prophet or other special person typically involving a revelation of events. Fortune-telling is the practice of predicting information about a person's life in a more informal manner. Judicial astrology is the art of forecasting future events by calculation of the planetary ad stellar bodies and their relationship to the earth. Natural astrology includes medical astrology and meteorological astrology, which were seen as being a part of the natural sciences at the time. Natal astrology involves reading the individual fates and horary astrology belongs to the category of answering specific questions or predicting specific events. 